\title{
TROTSKI, A DEMOCRACIA E O TOTALITARISMO \\ (a partir do Trotsky de Pierre Broué1)
}

RUY FAUSTO

A biografia de Trotski de Pierre Broué é um livro importante por mais de uma razão. Broué, historiador do mundo contemporâneo (devemos a ele, entre outras coisas, uma história do partido bolchevique e uma história da IIIa Internacional, livros sobre a revolução e a guerra da Espanha e sobre a revolução alemã, além de um texto... sobre a destituição de Fernando Collor...) é um grande conhecedor da vida e da obra de Trotski, provavelmente o maior. Editor das obras do lider bolchevique, diretor dos Cahiers Léon Trotsky, a sua biografia se baseia, entre outras fontes, nos "Trotsky's Papers" de Harvard, e nos papéis de Leon Sedov, filho de Trotski. Broué foi literalmente o primeiro a consultar a parte do arquivo de Harvard que só foi aberta em janeiro de 1980. Quanto ao arquivo de Sedov, que se supunha definitivamente perdido, ele foi identificado em Stanford, em 1985, pelo proprio Broué. O autor entrevistou, além disso, um grande número de contemporâneos de Trotski, inclusive Mario Pedrosa e Fulvio Abramo. Uma referência constante do livro, a quem, alias, ele é dedicado, é o lógico e matemático Van Heijenoort, co-descobridor do arquivo Sedov, que foi um dos secretários de Trotski de 1932 a 1939, e morreu assassinado no México, em 1985 (crime não político). Quem conhece a trilogia clássica sobre a vida e a obra de Trotski de Isaac Deutscher (O Profeta Armado, O Profeta Desarmado, O Profeta Banido), biografia admirada quase unanimemente no interior da galaxia não stalinista, descobrirá que o livro de Broué pretende ser também, entre outras coias, uma crítica ao trabalho de Deutscher. O autor não só corrige êrros de fato e imprecisões, mas se opõe a Deutscher no plano do julgamento político. Broué é trotskista, Deutscher foi membro do grupo polonês da oposição trotskista, mas teve

\footnotetext{
${ }^{1}$ Paris, Fayard, 1988.
} 
divergências com Trotski, às quais ele se refere en passant, no volume final da sua trilogia. Broué o acusa de "acertar contas" com Trotski, ao preço de certas concessões na leitura dos fatos. Não se conclua daí que o Trotsky de Broué é pouco objetivo. O livro tem evidentemente um viez polêmico, mas é um trabalho historicamente muito sólido, e embora publicado em 1988, até onde sei, ainda não foi superado. Por essa razão, e porque a discussão sobre Trotski e o bolchevismo é de atualidade em formas diversas, tanto na Europa como no Brasil, vale a pena tratar dele e tentar uma crítica dos seus pressupostos políticos.

A história de Trotski como militante revolucionário é extraordinária. Para entender os problemas que o livro de Broué levanta, é preciso contá-la com algum detalhe. Fugindo do exilio siberiano a que fora condenado, Trotski, que nascera em 1879, encontra Lenin em Londres, em 1902, o qual propõe o seu nome para o comitê de redação da Iskra. (Plekhanov impede que ele seja cooptado). Mas no congresso de 1903, em que se dá a cisão entre bolcheviques e mencheviques, Trotski acaba por apoiar a posição dos mencheviques. No ano seguinte, escreve Nossas Tarefas Politicas, um pequeno livro notável onde critica o bolchevismo e Lenin, e faz o processo do "substituísmo" (a organização do partido substitui o partido, o comitê central substitui a organização do partido, o chefe substitui o comitê central). No mesmo ano, abandona o grupo menchevique, sem aderir, entretanto, ao grupo oposto. Em 1905, com 26 anos, preside o soviete de Petrogrado, e vai presidi-lo de novo em outubro de 1917, dois meses depois da sua adesão ao bolchevismo. "Comissário do povo" para as relações exteriores do governo instalado após a insurreição de outubro (6, 7 de novembro, pelo novo calendário), insurreição de que ele é um dos principais senão o principal dirigente, participa da conferência de Brets-Litovsk, de que resulta o acordo de paz com as potências centrais. Em 1920, defende um projeto de "militarização do trabalho", e a integração dos sindicatos ao Estado. Mas começa a denunciar a burocratização do Estado e do partido. No posfacio ao seu "testamento", Lenin, que propusera a Totski um bloco contra a "burocracia", recomenda que Stalin seja afastado do posto de secretário-geral. Após a morte de Lenin, Trotski enfrenta a "tróica" Stalin-Zinoviev-Kamenev. Quando os dois últimos rompem com Stalin, constitui com eles a "oposição unificada" (1926). Exilado no Afaganistão em 28, expulso da URSS em 29, organiza no exterior a chamada oposição de esquerda, e funda em, 1938, a IV Internacional. Obrigado a sair da França e, depois, da Noruega, consegue asilo no México, onde, em agosto de 40, é assassinado por um agente de Stalin. 
O problema que levanta a posição de Trotski, como o bolchevismo em geral, e que um leitor do livro de Broué, não pode hoje, deixar de propor, é, numa primeira aproximação, o da possibilidade da coexistência de uma democracia interna num partido revolucionário dominante, com a ausência de democracia externa (embora houvessem instituições que conservavam a denominação de sovietes). Esse problema conduz a questões mais vastas, em ultima análise a da viabilidade do caminho revolucionário e da violência como opções preferenciais para a esquerda. A elas remete também o outro tema que importa discutir : o da natureza do regime russo antes e depois de 1924 / 25, e o da maneira pela qual Trotski o concebe. É claro que, nos limites desse texto, só poderei desenvolver parte dessa constelação de problemas.

Rigoroso no registro dos fatos, mas através de um recorte que será preciso pôr em discussão, o livro de Broué, embora não se fechando a toda crítica ao lider bolchevique, esposa em grandes linhas, o juízo de Trotski sobre a história do século XX e sobre o papel que ele teve nessa história. Broué consagra várias páginas a Nossas Tarefas Politicas, o livro anti-leninista de 1904. Mas se refere a ele como uma "diatribe loucamente excessiva contra Lenin (...) que, apesar de tudo, não havia excluído e a fortiori não havia executado ninguém" (sic) (p. 90). Que o texto do jovem Trotski possa ser considerado como premonitório (não no sentido de que o leninismo viria a realizar todos os passos no caminho do despotismo, previstos por Trotski, mas no de que o leninismo realizaria os dois primeiros, e o stalinismo o terceiro), fica fora do horizonte de Broué. No mesmo sentido, a descrição e a análise da insurreição de outubro e dos primeiros anos do poder bolchevique, comportando embora um certo número de críticas, vai na esteira da leitura de Trotski.

Na sessão de abertura do Congresso Pan-russo dos sovietes, que coincidiu com o levante de outubro (6, 7 de novembro), Trotski faz um pronunciamento célebre em resposta a Martov que propusera um acordo geral entre todos os partidos socialistas. Aludindo ao abandono da sala por uma parte dos representantes não bolcheviques que protestavam contra o levante de outubro, Trotski termina o seu pronunciamento com as seguintes palavras : "Aos que saíram e aos que nos dizem que façamos isto [um acordo com os outros partidos], devemos dizer : Vocês são 'destroços miseráveis, seu papel terminou, vão para onde deveriam estar : na cesta de lixo da história'" (Broué - p. 187 - cita por extenso só a parte da declaração que vem imediatamente antes desta; cf. N. N. Sukhanov, The Russian Revolution 1917, trad. ingl., Oxford Un. Pr., 1955, p. 640 ; e 
Leonard Shapiro, Les Origines de l'Absolutisme Communiste, les bolcheviks et l'opposition, 1917-1922, trad. francesa, Paris, Albatros, 1957, p.71). Broué não parece se comover com o episódio. Ora, o que se decidia ai era o destino da insurreição de outubro. Quem era Martov, o socialista que interpelava Trotski, e que, como os outros também estaria destinado, nas palavras de Trotski, "à cesta de lixo da história"? Era um velho militante menchevique internacionalista (ele morrerá no exilio em 1923), adversário do governo provisório, e que depois de uma longa luta, acabara por ganhar a maioria do partido menchevista. Uma atitude favorável por parte dos bolcheviques na noite da insurreição, ou pouco mais tarde, quando o Vikjel, o comitê pan-russo do sindicato dos ferroviários fez de novo a proposta de um governo plural (ver Broué, p. 207 e Shapiro, op. cit., p.74), talvez tivesse mudado as coisas. Mas os bolcheviques já haviam escolhido um outro caminho.

A análise do período "ultra-bolchevique" de Trotski (o seu percurso entre 1920 e 1921 foi assim denominado por um analista) é bastante objetiva e crítica. Entretanto, como Lenin se opõe a Trotski nas duas questões principais discutidas nesse período, a crítica de Broué não atinge o bolchevismo enquanto tal. A primeira questão aparece com a proposta por Trotski de um projeto de militarização do trabalho, que ele começa, alias, a pôr em prática no setor dos transportes, de que se tornara o responsável. A segunda é a sua atitude na discussão sobre os sindicatos. Trotski quer integrar os sindicatos ao Estado e fazer com que eles realizem a "sua verdadeira vocação" no interior do "Estado operário", isto é, pôr-se a serviço da produção. Por isso mesmo, ele é favorável às nomeações, em lugar de eleições, para o postos sindicais. "No Estado operário - afirma Trotski - (...) a existência paralela de organismos econômicos e de grupos sindicais não pode ser tolerada senão a título transitório (...) É preciso que os pensamentos e as energias do partido communista, dos sindicatos e dos organismos governamentais tendam a amalgamar os organismos econômicos e os sindicatos num futuro mais ou menos imediato" (Shapiro, op. cit., p. 231). Lenin se opõe a Trotski tanto a propósito de um ponto como do outro, embora, no primeiro caso, não imediatamente. A propósito da pretensa função essencialmente "produtiva" dos sindicatos no interior do "Estado operário", Lenin objeta com bastante lucidez : “(...) Um Estado operário é uma abstração. Na realidade, temos um Estado operário, primeiro com a particularidade de que é a população camponesa e não operária que predomina no país e, segundo, que é um Estado operário com uma deformação burocrática" (Broué, p. 286). Mas não nos iludamos com 
o democratismo de Lenin. Se ele se opôs ao ultra-bolchevismo de Trotski, a diferença entre os dois não era tão grande. Se o que afirma Leonard Shapiro é verdade (e não há razão para duvidar disso) nem Lenin e nem mesmo a chamada Oposição Operária propunham "dar aos operários o direito de eleger livremente os seus representantes e, em consequência, escolhê-los entre os partidos que desejassem" (Shapiro, op. cit. p. 237, 238).. A disputa não era entre sindicatos livremente eleitos e o Partido, mas entre a direção do partido e a sua fração sindical. Por isso, a vitória da posição de Lenin não significou muito. De resto, no final do X congresso do Partido, que se reune no momento da revolta de Cronstadt, Lenin apresenta duas moções, que foram aprovadas, uma condenando um "desvio sindicalista e anarquista" (referência à "oposição operária") e outra proibindo as frações e plataformas particulares no interior do partido, sob pena de exclusão.

A partir de 1922, começa a luta entre Trotski e Stalin, enquanto luta contra a burocratização interna do partido bolchevique. Falou-se bastante - ver os textos de Claude Lefort - sobre o imobilismo de Trotsky, no período 24/25. Broué descreve o processo, observando, com razão que, se Trotski foi criticado pela sua inação, poucos se deram conta da insuficiência da reação de Lenin. É só no ultimo momento, na realidade entre a redação do corpo do chamado "testamento" (dezembro de 22) e a redação do seu postfácio (janeiro de 23), que Lenin perde definitivamente as suas illusões com aquele que ele chamara de "magnífico georgiano"... Tarde demais : um novo ataque vai imobilisar Lenin até sua morte, em janeiro de 24.

A bandeira de Trotski é a da democratização do partido ; mas em que medida, ou em que limites, seria também a da democracia fora do partido? Durante um longo período, é apenas a democracia dentro do partido que ele reivindica. Ele escreve em Novo Curso: "É somente através de uma colaboração ativa, constante com a nova geração no quadro da democracia que a Velha Guarda conserva seu carater de fator revolucionário (...)". A "democracia" de que ele fala é evidentemente a democracia no interior do partido. (Cf. o resumo de outros textos de Trotski que vão no mesmo sentido, Broué, pp.784, 821 e 274). Entretanto, pelo menos a partir dos anos 30, já no exilio, ele começa a falar em liberdade para os "partidos soviéticos". Assim, em "Estado operário, Termidor e Bonapartismo”, lê-se o seguinte: “(...) O arbitrário burocrático deve ceder seu lugar à democracia soviética. O restabelecimento do direito de crítica e de uma liberdade eleitoral verdadeira são condições necessárias para o desenvolvimento do pais.O restabelecimento da liberdade dos partidos 
soviéticos (grifo de RF), a começar pelo partido bolchevique, e o renascimento dos sindicatos são implicações disso (...)”. (Broué, p. 823, cf. 943). Com isso, Trotski dá um passo adiante. Mas como conciliar essa proposta com a declaração de fé no bolchevismo? Enquanto ele fala apenas em democracia no partido, já existe um problema - ou um fato problemático - para alguém que reinvindica a herança do bolchevismo: a decisão, por proposta de Lenin, em 1921, de probir as frações. Esse problema é contornado sem muita dificuldade por Trotski, mediante a afirmação de que a medida era excepcional, e imposta por uma conjuntura muito especial (ver Broué, p. 560). Mas a justificação é mais dificil quando se propõe a liberdade para todos os partidos "soviéticos". Tal reivindicação vai em cheio contra a prática do bolchevismo, e não é remetendo ao carater excepcional da proibição das frações em 1921 que se resolverá a dificuldade. No caso da resolução de 1921, já vimos, o que está em jogo é a liberdade interna do partido. Da liberdade externa, isto é, para os outros partidos, nem se cogita. (cf. Shapiro, op. cit., pp. 291, 292) Nos anos 20 - ja disse - Trotski é evidentemente um adversário da legalização dos outros partidos "soviéticos" (ver também Broué, p. 315). (Pelo que parece, só um homem dentro do partido bolchevique foi desde o início favorável à liberdade para todos os partidos, G, I. Miasnikov ; ver a respeito, Shapiro, op. cit., principalmente, pp. 270 e 345 , n. 36 e 37. Detalhe interessante : obrigado a abandonar a URSS - é Broué quem nos conta - Miasnikov, que estava numa situação material muito dificil, vai procurar Trotski na Turquia. Este o ajuda a ganhar a Europa ocidental. Da conversa que tiveram os dois, tudo o que nos é informado é que Trotski o aconselha a não se deixar levar pelo ressentimento ( Broué, p. 620)). Justificando, nos anos vinte, o monopólio do partido bolchevique Trotski se vale do argumento de que "a maioria dos mencheviques" e os sociais-revolucionários estariam a serviço dos brancos e da contra-revolucão (ver Broué, p. 274). Porém isso é duvidoso para o momento da guerra civil: a direção mechevique se propôs apoiar o poder bolchevique, e mais do que isso, mencheviques lutaram e morreram sob uniforme "vermelho". Mas o problema de base é o da politica bolchevista em relação aos "partidos soviéticos" no periodo anterior, isto é, logo após o movimento de outubro. Na realidade, embora tenham feito uma aliança com a esquerda dos sociais-revolucionários (mas era uma aliança tática feita para não durar, como o próprio Trotski o reconhece), os bolcheviques foram liquidando progressivamente as outras tendências, e asfixiando os sovietes. De tal modo, que no verão de 18 , antes que a guerra civil tivesse realmente começado, os sovietes já eram um simulacro de poder popular 
(ver a respeito Shapiro, op. cit.). (A propósito: o que são exatamente "partidos soviéticos"? Observo. Depois de retomar uma palavra de ordem de tipo análogo, "liberdade para todos os partidos operários", um documento da IV Internacional, dos anos 60 ou 70, assinado por um de seus dirigentes, Ernst Mendel, explicava em nota : "o soviete decidirá quais são os partidos operários". Soviéticos seriam assim, os partidos que o soviete designaria como tais. Mas mesmo supondo uma verdadeira democracia no interior dos sovietes, eles legalizariam partidos republicanos que não fossem de esquerda? Na visão e no projeto de Mandel, a resposta seria, sem dúvida, negativa.) Pelo menos em uma ocasião, na sua deposição à Comissão Dewey, que fôra constituida para julgar do valor das acusações lançadas contra ele e outros dirigentes bolchevistas nos processos de Moscou, Trotski vai mais longe do que a posição de defesa dos "partidos soviéticos". Além de afirmar que "os paises civilizados e não isolados terão uma ditadura democrática mais sã e mais democrática (sic) e por menos tempo" (Trotski, citado por Broué, p. 861), ele declara que a instauração do partido único na Rússia foi uma "medida de guerra" e que um futuro regime revolucionário autorizaria vários partidos "não excluindo de forma alguma - Broué resume Trotski - em função das circunstâncias e de uma grande estabilidade do regime, um partido pró-capitalista" (Broué, p. 862). Esse texto é surpreendente. De duas coisas uma : ou se trata de uma manifestação episódica cujo teor se explica por razões táticas; ou Trotski modifica muito a sua atitude primitiva sobre a questão, o que conviria explicitar e reconhecer. Nada nos leva a crer que nos anos 20, Trotski considerasse o monopólio do partido bolchevique como um caso particular, justificável pelas condições russas. De um modo geral, interessaria saber em que momento preciso Trotski começa a falar em liberdade para os "partidos sovieticos". Broué passa rápido demais sobre o assunto. Como vimos através de um exemplo, o movimento trotskista teve - e continua tendo - um papel ambiguo em relação à questão da democracia. Só recentemente um dos principais grupos trotskistas francêses resolveu abandonar a palavra de ordem da "ditadura do proletariado". O que o "renegado" Kautsky propusera já em 1918...

A outra questão importante é a da maneira pela qual Trotski vai pensar a ditadura stalinista e o destino da revolução.. Conhece-se a concepção de Trotski a respeito do regime russo após a morte de Lenin em 1924. Devido ao atraso do país, às derrotas da revolução nos paises capitalistas mais avançados, e a uma espécie de esgotamento do proletariado em consequência das dificuldades do período pos-revolucionário e da guer- 
ra civil, o poder cai nas mãos de uma burocracia. A burocracia não é uma nova classe, mas uma espécie de casta, que expropriou o proletariado ; mas por isso mesmo, o Estado "soviético" não perdeu o seu carater revolucionário. É preciso continuar a defender o "Estado operário", apesar da burocracia. Uma vez quebrado o isolamento international da URSS, a burocracia acabará por ser derrubada por um movimento, que não representará uma "revolução social" mas simplesmente uma "revolução política". Como o Estado Soviético continua tendo um carater revolucionário e "operário" (sic), a revolução na URSS visará simplesmente a desapropriação do poder político da burocracia, e não mais do que isto.

A meu ver, há na concepção de Trotski uma mistura de erros, de acertos, e também de pontos discutiveis. Porém, pelo menos se pensarmos nas implicações políticas da sua posição, há bem mais erros do que acertos, e o preço desses erros foi alto para o destino das idéias socialistas, na medida em que Trotski encarnou, e ainda encarna para muita gente, a luta contra o despotismo burocrático. $\mathrm{O}$ acerto está na idéia do carater transitório da ditadura burocrática. De fato, embora ainda subsistam alguns restos, como sistema ela não durou mais do que meio século, e na URSS pouco mais de 70 anos, o que no registro da grande história, pelo menos em primeira aproximação, não é muito. (Lenin acreditava que a ditadura do proletariado na URSS duraria uns 80 anos... Depois dela, começaria, segundo ele, o processo de passagem, digamos, não mais "pré-histórica" mas "histórica" ao comunismo). Há, na concepção de Trotski, coisas que poderiam ser discutidas, como a idéia de que a burocracia não é uma classe (a meu ver, suposto um emprego da noção de classe um pouco diferente do uso - mais do que da noção - marxista, a resposta seria, a meu ver, que ela é). Errada propriamente é a idéia de que o Estado soviético seria (e teria continuado a ser, até o final dos anos 30 (Trotski morre em 1940) um Estado "revolucionário" em sentido progressista, ou um Estado "operário". Analisar as dificuldades da teoria de Trotski é muito importante, porque nos conduz a refletir sobre as relações entre o bolchevismo e o stalinismo e entre o bolchevismo e o maxismo; e a partir daí a refletir sobre a validade teórica e política do marxismo. De fato, a discussão nos leva a pensar o significado dessas très "figuras", marxismo/ bolchevismo/ stalinismo, e as relações de continuidade ou de descontinuidade que podem exister entre elas.

A posição de Trotski tem dois pressupostos, o da descontinuidade radical entre leninismo e stalinismo, e o da continuidade, pelo menos essencial, entre marxismo e leninismo. O pressuposto mais geral é a idéia de história do marxismo. 
O "destino" (embora não fatal) da história do século XX seria a tomada do poder pelo proletariado. O partido bolchevique "representaria" o proletariado, o que não poderia ser dito de outros partidos socialistas russos. O movimento de outubro, dirigido pelo partido bolchevique, seria assim uma revolução proletária. E o que a sucedeu, uma ditadura do proletariado, encarnada pelo único partido que representava o proletariado. Porisso mesmo, nessa ditadura, esse partido, no interior do qual deveria haver democracia e livre discussão interna, teve de ser o único partido legal. Desse modo, como vimos, coexistem democracia, no plano interno do Partido, e ausência de democracia (entenda-se, ausência de uma pluralidade de posições com eficácia política, potencial pelo menos) no plano da sociedade civil e do Estado. Para Trotski, essa situação, que para um olhar crítico aparece como intrinsicamente instavel, não explicaria em nada o destino da revolução. Em algum lugar, Trotski disse aproximadamente que não seria possível explicar algo tão importante como o "descarrilhamento" da revolução a partir da natureza de um partido e da atitude desse partido em relação aos demais. $O$ fenômeno stalinista teria outras razões, que ele supõe sejam mais profundas. De minha parte diria que outros fatores também houve, mas que Trotski subestima as potencialidades despóticas do bolchevismo, e em geral o "peso" do politico.

Para justificar a idéia de que a burocracia é uma "casta" e não uma classe, Trotski se vale do argumento de que ela não teria papel autônomo na produção e na repartição. "Ela não tem um lugar independente no processo de produção e de repartição. Ela não tem raízes independentes de propriedade, Suas funções se relacionam, essencialmente, com a técnica política da dominação de classe. A presença da burocracia, com todas as diferenças das suas formas, e do seu peso específico, caracteriza todo regime de classe. Sua força é um reflexo. A burocracia, indissoluvelmente ligada à classe dominante, se nutre através das raízes sociais desta ultima, mantem-se e cai com ela." (Broué, p.772, grifos de PB). Por isso a revolução anti-burocrática não seria uma revolução social : "Se hoje na URSS surgisse no poder um partido marxista, ele restauraria o regime político, mudaria, purificaria e dominaria a burocracia através do contrôle das massas, transformaria toda prática administrativa, introduziria uma série de reformas capitais na direção da economia, mas de modo algum teria de realizar uma mudança revolucionária (bouleversement) nas relações de propriedade, isto é uma nova revolução (revolution) social' (p. 773, grifo de LT2).

2 Ver, sobre esses textos, TROTSKY, Léon, Ouvres, vol. 2, julho 1933/ outubro 1933, publicadas sob a direção de P. Broué. Introdução et notas de BROUE, P. e DREYFUS, Michel, "La 4 ème Internationale et l'URSS. La nature de classe de l'État soviétique”, p. 243 a 268, Paris, Edi, 1978. 
O que dizer desse esquema? O melhor é começar do começo, isto é, criticando os fundamentos primeiros do argumento. Não é verdade - ou pelo menos, hoje, nada nos leva a crer - que a revolução proletária seja a "perspectiva", isto é, o futuro ao mesmo tempo provável e desejável (mesmo se o marxismo não diz, inevitável) da história do século XX. A perspectiva poderia ser, digamos, um estado democrático radical, com propriedade privada e dinheiro, mas, no limite, com o desaparecimento ou uma neutralização efetiva do capital. Se for assim, pelo menos como hipótese preferencial, nem a revolução proletária nem muito menos a ditadura do proletariado aparecem como "necessárias". O que, por sua vez, ilumina de um modo diferente a política bolchevique. Já é duvidoso que o partido bolchevique "represente" o proletariado ou mesmo a vanguarda do proletariado. De fato, essas noções só têm pleno sentido, se admtirmos o esquema marxista da história, em particular no que se refere à história dos séculos XIX e XX. Na realidade, o que houve foi a tomada do poder por um partido radical, apoiado, sem dúvida, por uma massa importante de operários e de soldados. Esse partido, formado por gente com idéias revolucionárias, muito cedo pôs na ilegalidade os demais partidos, inclusive os de esquerda. Houve erros mas também acertos na politica desses partidos de esquerda.. Com relação ao menchevismo, seria bom lembrar que a sua ala esquerda, comandada por Martov, a qual propunha a ruptura com o governo provisório, acabou sendo majoritária precisamente no momento da insurreição. Em janeiro de 18, o poder dito "soviético" fechou a Assembléia Constituinte eleita em novembro, na qual o partido bolchevique era minoritário. (Se, como argumentaram os bolcheviques, a assembléia fora eleita a partir de uma situação politica e de listas eleitorais que tinham envelhecido, havia uma solução indicada por Rosa Luxemburgo ${ }^{3}$, adversária do fechamento : dissolver a Assembléia - em lugar de "dispersá-la" - e convocar novas eleições...). O regime que se instala é assim progressivamente (já no verão de 18, antes da guerra civil) um regime de ditadura de um partido. O que caracteriza essa ditadura? Uma de suas características é precisamente a de que, dentro da instituição que exerce a ditadura, o partido bolchevique, existe um regime democrático, ou até certo ponto democrático. A outra característica, ainda relativa à instân-

3 Ver LUXEMBURG, Rosa, Gesammelte Werke, Band 4, August 14 bis Januar 19, "Zur russischen Revolution”, p. 353, 354, Berlin, Dietz, 5th Auflage, 1990. 
cia dirigente, é a de que o corpo dessa instância, é constituido por gente dominada por um ethos de transformação radical e "popular" das instituições. Isso significa alguma coisa, mas não se confunde com a idéia de que o que se tem é um partido representante do proletariado, através do qual o proletariado exerce a sua ditadura. Essa ditadura de tipo "igualitarista" se exerce na realidade sobre todas as classes, inclusive sobre o proletariado, e isto talvez desde o início ou, de qualquer modo, muito cedo (ver a respeito, Kautsky, A Ditadura do Proletariado ${ }^{4}$ ). Esse o quadro até 23/24. Como se passa dessa situação à que se tem após 1924? É falso, totalmente falso, dizer que houve simples continuidade. Mas também não houve simples descontinuidade essencial. Há duas mudanças na instituição que exerce a ditadura ( em se tratando de uma ditadura, aliás de um tipo particular, o que se passa no plano do Estado tem um peso decisivo). Há uma mudança no governo dessa instituição (se se quiser, na instância política dessa instituição, ela mesma política no seu projeto e na sua situação efetiva). Passa-se de um regime interno de democracia a um regime interno de ditadura. O que vai significar uma mudança fundamental: um desdobramento do poder entre o partido e um déspota (não confundir com uma simples aparição de um "líder poderoso" no interior do partido). A outra mudança atinge o conjunto do partido, porém mais especialmente o que poderíamos chamar a sociedade civil da instituição que exerce a ditadura, isto é, o corpo do partido. Este corpo, e o partido em geral, se caracterizavam, dissemos, por um ethos revolucionário. Esse ethos se modifica progressivamente, e toma um outro caráter, que pode ser chamado de "burocrático". Sob o primeiro aspecto, surge assim a figura do déspota. Sob o segundo, cristaliza-se uma burocracia com interesses próprios. (A burocratização é um fenômeno que vai além do partido : surge não só uma burocracia de partido, mas uma burocracia de Estado, que aliás, em parte, tem os mesmos portadores. Por outro lado, ao processo de burocratização dos membros do partido, corresponde, na sociedade civil propriamente dita, uma mudança na atitude das classes populares que vão do radicalismo ao indiferentismo). Como se efetuam essas passagens? Há qualquer coisa de inevitável na primeira. A coexistência entre democracia interna e autocracia externa é em si mesma extraordinariamente instável. É difficil que o autocratismo dominante na sociedade global não acabe por se refletir den-

\footnotetext{
4 A esse respeito, permito-me remeter ao meu texto "Kautsky e a crítica do bolchevismo", publicado sob o titulo "A polêmica sobre o poder bolchevista, Kautrsky, Lenin, Trotsky", Lua Nova, 53, 2001.
} 
tro do partido. Democracia interna e poder "externo" autocrático, dificilmente coexistem. O que significa: a idéia da ditadura de um partido internamente democrático é em princípio utópica ; baseia-se numa ilusão voluntarista. Mas há também a outra passagem, a do ethos revolucionário ao ethos burocrático. É dificil manter um ethos revolucionário para além do período imediato da tomada do poder : há uma espécie de estabilização inevitável. A dificuldade e os contra-poderes que seria possível mobilizar são similares aos do caso anterior. Havendo democracia, essa estabilização pode ser controlada de algum modo. Não havendo, uma vez arrefecido o entusiasmo revolucionário, é quase inevitável que os membros do partido e os funcionários do Estado façam valer seus interesses imediatos sem muita preocupação com o interesse global do pais, e que eles se "cristalizem" em burocracia. Diria assim que se só a democracia no plano global é uma garantia de democracia dentro do partido dominante, de novo, só a democracia pode senão garantir em absoluto, pelo menos oferecer alguma garantia, de que o inevitável arrefecimento do ethos revolucionário não degenere em puro e simples ethos burocrático. Mas aqui somos levados a uma problemática mais geral. Aquém dos problemas da degenerência despótica e da degenerescência burocrática das revoluções, é preciso se perguntar se, em geral , a "Revolução" se justifica. Se na situação inicial tinha-se um governo democrático, o que foi dito sobre o processo inevitável em direção ao despotismo, significa finalmente questionar a própria idéia de revolução. Se não havia democracia, e a revolução aparecera como unica saida, de certo modo talvez como mal menor, é essencial que o poder revolucionário institua a democracia, nas melhores condições possíveis. Na base dos meus argumentos, está, sem dúvida, uma visão não muito otimista do comportamento de indivíduos e grupos. Mas o diagnóstico parece realista, e remete essencialmente a uma recusa do voluntarismo revolucionário. Em lugar da visão voluntarista, é preciso pensar em termos de formas, e supor uma inércia inevitável do poder revolucionário. Não se pode viver indefinidamente "em tensão". Se a revolução foi inevitável, a solução não é exigir uma espécie de tensão permanente, mas assegurar que a inevitável baixa de tensão não implique em sinal verde a novas formas de opressão e exploração. Com o que, não pretendo negar que as condições particulares da Russia tiveram o seu papel no processo. Mas a partir da experiência do século XX, é possivel concluir que essas condições só agravaram a situação, e que, não havendo democracia, o deslizamento é, sempre, mais ou menos inevitável. De fato, o projeto revolucionário em sentido estrito se revelou um mito extremamente 
perigoso. Em vez de justificar os horrores e violências a partir dele ou em nome dele, é preciso pô-lo entre parênteses - pelo menos em principio como um caminho perigoso que não justifica nada, já que ele mesmo é a fonte intrínseca das suas deformações. Em vez de dizer, como se continua ouvindo : isso é inevitável nas revoluções, "não se faz omelete sem quebrar os ovos", é preciso perguntar se, hoje, as revoluções se justificam, se elas representam efetivamente uma via de progresso. Como já se disse a propósito dessa perigosa imagem justificativa, é preciso verificar de que omelete se trata, para depois verificar se valeu a pena quebrar os ovos. Contra preconceitos arraigados na esquerda durante dois séculos, acabaremos descobrindo que o omelete estava estragado, ou que, ao contrário do que acontece na cozinha, em politica, ele estraga com a quebra dos ovos. O melhor é preparar um outro prato.

Trotski descreve o processo em termos de "burocratização". Não que o termo "despotismo" esteja ausente (ver Broué, p. 916). Mas o termo, em Trotski, indica antes uma característica da burocracia, e não tem o estatuto de conceito substantivo. Não se trata de um simples problema de terminologia. Trotski define a "degenerescência" do partido, a partir do "corpo" do partido, e da sociedade global, não a partir das "instituições politicas" do partido, isto é, do que se passa propriamente na sua direção: o despotismo de Stalin seria de certo modo epifenômeno da burocracia. De Stalin, Trotski dirá mesmo que ele é a quintessência da burocracia. O que é um erro, como Castoriadis, e depois dele outros autores já observaram. Trotski é incapaz de pensar o déspota como sendo ele mesmo uma instituição (voltarei a esses pontos, com mais detalhes e bibliografia, em outro lugar5). Ele não vê como fenômeno próprio a figura do déspota que domi-

5 No que escrevi sobre os totalitarismos de esquerda, na "Introdução Geral" ao terceiro volume do meu Marx : Lógica e Politica, vol. III (Ed. 34, 2000), a noção central é a de "burocracia" e não de "despotismo". Comecei a insistir no problema do despotismo num texto de abril de 2003 "Cuba sim, ditadura não", publicado em caderno especial pelo Correio Braziliense; e depois em passagens de dois textos publicados na imprensa de São Paulo. Ver minha entrevista à Folha de São Paulo, de 29 de Fevereiro de 2003, e meu artigo "A esquerda na encruzilhada", no suplemento Mais! da Folha, de 11 de janeiro de 2004. Claro que a referência ao despotismo não elimina a referência à burocracia. Trata-se, no caso, de uma espécie de "despotismo burocrático".Tentando formular conceitos, diria que temos aí um "despotismo burocrático 'igualitarista"” e isto em oposição aos "despotismos burocráticos anti-igualitários (fascismo etc)". (Explicando: os despotismos burocráticos "igualitaristas" são só na aparência - mas na aparência o são - igualitários, porisso aponho o "istas", sufixo semi-negativo. Os anti-igualitários, pelo contrário, são plenamente contra a igualdade : sua denominação não exige nem comporta o sufixo). 
na o partido e o país 6 . Quanto à burocracia, mesmo se ela aparece como primeira - e, sem dúvida, excessivamente "primeira" - em relação ao déspota, Troski insiste em fazer dela uma formação dependente de uma classe (isto é, de uma formação que, para ele, merece o nome de "classe"). Mas que classe seria esta ? Trotski faz a pirueta teórica de localizar no proletariado a classe que a burocracia "soviética" parasitaria. A mediação estaria na economia planificada e na propriedade estatal. Estas seriam as marcas da presença - presença-ausência, mas, mesmo isto, é, sem dúvida, excessivo - do proletariado, e revelariam a substância de que a burocracia é acidente. (É verdade - mas não basta - que Trotsky considera a burocracia "uma formação social extremamente poderosa" ( Broué, p. 916)). A burocracia parasitaria o "estado operário". Aqui entramos num discurso quase da ordem do mito. Que significa "estado operário", se é que significa alguma coisa? Um estado que nasceu de uma insurreição de caráter supostamente "operário"? Como vimos, essa caracterização histórica é duvidosa. Porém mesmo que ela fosse correta, não diria nada, ou diria

6 Um problema correlato à questão do "despotismo", é o da atitude de Trotski em relação aos genocídios ou similares, praticados pelo poder stalinista, em particular o genocídio dos camponeses em 1932/33. A proposito do genocidio de 32/33, Broué (p. 700) escreve que "com a etiqueta de "kulaks"- os quais não eram mais do que dois milhões - as vitimas foram sete milhões de camponeses médios e pobres : [houve] mais mortos do que numa guerra". Primeira questão : Trotski estava a par da extensão que tomara a liquidação fisica direta ou indireta de kulaks e assimilados ? Uma passagem de um artigo de NOVE, Alec, "Trotsky, markets and Europeans Reform" in NOVE, A., Studies in Economics and Russia, N. York, St Martins Press, 1990, p. 76, sugere a possibilidade de que, pelo menos em 1932, ele não sabia da extensão (qualitativa ou quantitativa ?) dos horrores. Mas em A Revolução Traida escrita $_{\perp}$ em 1936, Trotski escreve que "as perdas humanas (...) (...) se contam (...) em milhões" (TROTSKY, L., La Révolution Trahie, introdução de Pierre Franck, Bélgica, E. Decoux, s/d, p. 35). Trotski foi certamente contrário aos métodos brutais empregados por Stalin no campo (ver a própria Revolução Traida, e também o texto referido de Nove, além de outros do mesmo autor) porém a própria maneira pela qual é apresentada a realidade do exterminio, mostra que este não aparece com todo o peso que lhe é proprio, mas, de algum modo, não mais do que como um episódio ou peripécia, terrivel embora, na trajetória de uma forma deformada ou degenerada de "Estado operário". É verdade que uma primeira leitura dessa mesma passagem da Revolução Traida poderia nos levar à conclusão contrária, já que Trotski, depois de fazer o balanço das perdas em termos de produção agricola e de pecuária, observa : "As perdas em homens - de fome, de frio, em consequência das epidemias e da repressão infelizmente não foram registradas com a mesma exatidão que as perdas em gado (...)".(ib) (segue-se a referência aos milhões de vítimas). Porém uma observação dessa ordem, por crítica que seja, é ainda fraca, a meu ver, diante do que era, e Trotski o diz, o exterminio de milhões de pessoas. O genocídio, essa categoria de certo-modo transhistórica, ficava fora da visão da historia do marxista Trotski. A impossibilidade de ver o genocidio em toda a sua significação, digamos, antropológica, tem algo a ver (na medida em que o marxismo está por tras das duas insuficiências) com a ocultação relativa do fenômeno do "despotismo". 
muito pouco, sobre a situação presente. Quanto a afirmar que a burocracia não tem "lugar independente no processo de produção e de repartição" (Trotski, citado por Broué, p. 772), a tese é evidentemente falsa. Além de participar da produção imaterial através de alguns de seus estratos, ela está no centro dos mecanismo de distribuição da riqueza. Bem entendido, ele é beneficiária da atividade de outras classes, mas isso ocorreu até aqui com todas as classes dominantes. Trotski diz que a burocracia sempre serviu a uma "classe", o que não deve ser inteiramente verdade, porque, em outras situações históricas, burocracias atingiram maior ou menor autonomia. Porém com a experiencia russa, temos um caso particular, um caso limite. Uma burocracia que não só não é instrumentalizada por uma outra classe (embora ele esteja submetida a um déspota), mas que se justifica através de uma ideologia eminentemente revolucionária e "progressista". Esta não é a única novidade da situação. Na realidade o novo é em geral o próprio fenômeno de um despotismo burocratico instalado numa sociedade industrializada do século XX. O "uso" de uma idéologia revolucionária como o marxismo, ao mesmo tempo Aufklârer e crítico da Aufklärung, se explica nesse contexto. O que resta de verdade, como ja disse, é que a história do século XX parece mostrar que as burocracias de tipo "comunista" tiveram uma longevidade limitada, o que poderia implicar que elas não são pelo menos "grandes classes". Entretanto, ainda que admitissemos que a burocracia não possa ser subsumida como "grande classe" isso não significaria uma vitória importante para a posição de Trotski. Porque o mais importante aqui são duas coisas: 1) que o surgimento de um sistema despótico-burocrático com uma idéologia igualitarista não leva Trotski a repensar o conjunto do esquema marxista da história, o que de qualquer modo se impõe. Em vez de se perguntar se a burocracia pode ou não ser subsumida pelo conceito marxista de classe, seria preciso perguntar, inversamente, se a visão marxiana da história resiste à experiência do século $X X$, com seus despotismos burocraticos etc ; 2) que a afirmação de que a burocracia não é classe serve para fornecer apesar de tudo uma justificação histórica ao regime stalinista, o que é um erro. De um modo geral, como já disse em outra ocasião (ver meus textos, referidos em nota) Trotski tem dificuldade para pensar o problema do despotismo, porque essa figura está ausente como conceito, no discurso marxista. $\mathrm{O}$ que se tem como conceito, no marxismo, é ou o despotismo oriental, que é uma figura muito arcaica, ou então o bonapartismo. Trotski tentou utilisar a noção de bonapartismo para pensar o stalinismo, mas o resultado foi muito insuficiente. Também a noção de Termidor, na qual ele se enreda. Bonapartismo pode ser entendi- 
do a partir do primeiro Bonaparte ou do segundo (Napoleão III). Na tradição marxista, ambos representam poderes "fortes" que eliminam o dominio "direto" do Estado por uma classe, mas para realizar os interesses "históricos" dessa classe. No primeiro caso, de uma classe ainda revolucionária, no segundo dessa mesma classe, mas já na sua trajetória "defensiva" diante de um proletariado que se supõe ascendente e ameaçador. A burocracia teria tido esse papel em relação ao proletariado. Mas se a burocracia não garante a dominação de nenhuma outras classe, essa conceituação não se sustenta. Quanto ao conceito de Termidor, Trotsky hesita sobre a definição dele e acaba pensando "Termidor" não como uma contra-revolução radical, mas aproximadamente como um movimento que prepara o "bonapartismo". Ao se decidir por essa leitura, dirá que o Termidor russo se deu em 1924. As dificuldades dessa comparação, nas suas diferentes versões, são análogas às que atingem a noção de "bonapartismo". E a insuficiência da explicação de Trotski tem a ver com o seu apego ao esquema marxista para a história "futura", e em geral, com as debilidades do marxismo no plano da teoria política.

No seu ultimo ano de vida, Trotski teria modificado a sua posição, e buscado uma apresentação do destino politico da URSS em termos menos apegados à tradição marxista ? É a leitura que já fora sugerida anteriormente, creio que por Boris Souvarine. Broué se refere a ela. "O campo permanece ( ...) aberto para as hipóteses mais contraditórias (...) Como crêem alguns, [Trotski] era um 'homem novo' nesse verão de 1940, rompendo consigo mesmo e com a análise que ele mesmo fizera da URSS alguns meses antes? Invoca-se para apoiar essa opinião o seu Stalin inacabado, os fortes epítetos que ele emprega para caracterizar o ditador que ele compara a Nero, o emprego [que ele faz] provavelmente pela primeira vez do termo 'totalitarismo', para caracterizar o regime stalinista. Alguns vêm mesmo em 'O Komintern e a GPU', análise prática da rede de serviços no seio da Internacional, o esboço de uma análise nova dos partidos comunistas e da Internacional, [como] agências do Kremlin, pura e simplesmente" (Broué, p. 940). Nesse contexto, Broué evoca um escrito pouco anterior de Trotski, em que este afirma que se a guerra não provocar a revolução mas o declinio do proletariado, dever-se-ia concluir que o proletariado se revelou incapaz de tomar o poder, e admitir que surgiria uma nova classe exploradora a partir da burocracia. Seria "o crepúsculo da civilização" ( Broué, p. 917) e, resume Broué, isto obrigaria a "rever a perspectiva marxista" e a idéia de que haveria "uma revolução socialista" (p. 942). Segundo Broué, Van Heijenoort, que conhecia muito bem a vida 
e o pensamento de Trotski, julgava que esse texto representava bem o pensamento do último Trotski e que este estaria, então - a expressão é de Heijenoort - "disposto a cortar (retailler) a barba de Marx" (p. 942). Observe-se que se esse último texto marca certamente um progresso porque Trotski admite a possibilidade de que o rumo que toma a história contemporânea obrigue a pensar "para além" do marxismo, ele tem o inconveniente de supor que a burocracia, ou a classe que seria sua herdeira, teria um longo futuro histórico, o que os acontecimentos parecem ter desmentido. Aliás, o tema do "crepúsculo da civilização" tem algo de uma leitura marxista ou marxizante com sinais trocados. Nesse sentido, os textos do Stalin talvez sejam mais interessantes. Broué affirma que ele e "Van" buscaram outros escritos de Trotski que iriam na mesma direção. Van projetara mesmo escrever um texto a respeito, mas teve de renunciar, por não ter encontrado o que buscava. Broué, cuja posição é a clássica, parece cético em relação a essa virada final de Trotski.

Concluindo. Trotski, e Broué com ele - isto não significa que o livro não contenha críticas a Trotsky, mas em geral estas se referem, ou a problemas adjetivos, ou a problemas que não atingiriam o conjunto do poder bolchevista, ou a questões atinentes ao individuo Trotsky e ao seu estilo no plano da vida cotidiana (há aí algumas surpresas) - recusa-se a admitir qualquer continuidade (senão de fato) entre o bolchevismo e o stalinismo (o que não o impede considerar a ditadura da burocracia como expressão deformada da ditadura do proletariado) e passa rapido demais, na maturidade, sobre a idéia de que possa haver uma descontinuidade entre marxismo e bolchevismo. Nos seus escritos, a valorização do bolchevismo vai junto com a valorização do marxismo. As coisas parecem bem mais complexas. Uma possibilidade, que não é a minha, seria a de "salvar" o marxismo, estabelecendo uma descontinuidade entre marxismo de um lado, e bolchevismo-stalinismo de outro. Na realidade, há alguma descontinuidade entre os três elementos : marxismo, bolchevismo e stalinismo. Como escreve Shapiro no prefácio do livro citado, "Marx nunca disse que um único partido revolucionário deve suplantar e destruir todos os outros partidos operários e camponeses, para se estabelecer sozinho no poder" (Shapiro, op. cit., p. 10). Por sua vez, há certamente descontinuidade entre leninismo e stalinismo. Não é preciso refletir muito para se dar conta de que as práticas de Stalin com relação aos membros do partido são estranhas às tradições leninistas. Assim, há descontinuidade entre esses tres termos. Porém, há tambem continuidade entre eles. É evidente que a repressão contra os outros partidos de esquerda por parte do poder bolchevique e o asfi- 
xiamento de toda democracia mesmo "soviética" (duas coisas que, como vimos, contra a lenda vigente, não se justificam pela guerra civil, mesmo porque ocorrem antes dela), criaram as condições - sem dúvida houve também fatores globais - que tornaram possível a emergência do poder stalinista. Por outro lado, se Marx não é responsavel pelas práticas "antisoviéticas” de Lenin, não há dúvida de que o projeto de transformação violenta e a idéia de ditadura do proletariado (mesmo se Marx, e Engels ainda mais, a pensou em forma transitória e de certo modo "excepcional") abriram caminho para a violência bolchevique. Assim : nem confusão ou simples continuidade entre os tres projetos, nem justificação do primeiro (e $a$ fortiori dos dois primeiros), com base na descontinuidade. O projeto revolucionário de Marx, e principalmente a "figura" da ditadura do proletariado (quaisquer que tenham sido as precisões e precauções primitivas), mais do que isto, eu diria, a idéia geral de história - sobretudo da historia futura (o comunismo) - de Marx, abriram as portas para um cerceamento funesto da democracia, inclusive da forma particular e, de certo modo, limitada, que seria a democracia soviética. Os passos dados nesse sentido pelo bolchevismo significaram por sua vez - involuntariamente sem duvida, pelo menos para a maioria dos dirigentes bolcheviques - a ruptura de todos os mecanismos de defesa contra a ditadura sem principios e genocidária que acabaria por se instalar. Como dizia Trotski, passou-se da violência revolucionária à violência pura e simples.(p. 889). O que é verdade, mas, já na sua primeira forma pré-bolchevista, a primeira não era tão consistente como se supos. A história do século XX mostra que ela traz no bojo a sua própria transgressão. Um ferroviário francês que visitou Trotski na Turquia e a quem ele explicou sua concepção do partido e o projeto da IVa. Internacional perguntou a Trotski se o que ele propunha era "recomeçar tudo". Ele respondeu que sim (Broué, p. 763). Mas "recomeçar" se diz em dois sentidos. Refazer o que tinha sido feito, ou fazer de outro modo. Apesar de algumas mudanças, Trotski e os trotskistas optaram pelo primeiro sentido. Querem retomar o passado, mesmo se introduzindo um certo número, limitado, de alterações. O movimento se faria ainda sob a bandeira do marxismo e do bolchevismo. A experiência do seculo XX e do início do nosso nos convida, pelo contrário, a tentar um começo realmente novo. Nesse sentido, apesar da grandeza indiscutível do personagem, nos seus melhores momentos pelo menos, Trotski representa o passado.

RUY FAUSTO é professor emérito da FFLCH-USP. 